\title{
ISOLASI DAN KARAKTERISASI SENYAWA GLIKOSAMINOGLIKAN DARI ORGAN IKAN PARI (Trygon sephen)
}

\author{
Thamrin Wikanta"), Riyadini Perwita"), Prih Sarnianto"), dan Murdinah")
}

\begin{abstract}
ABSTRAK
Tulisan ini melaporkan hasil penelitian tentang isolasi dan karakterisasi senyawa glikosaminoglikan dari beberapa organ ikan pari (Trygon sephen) yang mencakup proses ekstraksi melalui tahapan pencernaan, presipitasi dan pemurnian, serta identifikasi senyawa menggunakan teknik spektrofotometri inframerah, khromatografi cair kinerja tinggi dan elektroforesis. Ekstraksi dilakukan melalui proses hidrolisis enzimatis dengan menggunakan enzim papain $3 \%$ dalam larutan buffer fosfat $\mathrm{pH} 6,5$ pada suhu $65^{\circ} \mathrm{C}$ selama 24 jam. Ekstrak kasar didapatkan dengan cara pencernaan dilanjutkan dengan presipitasi menggunakan alkohol teknis dan selanjutnya ekstrak kasar dimurnikan melalui kolom kromatografi menggunakan resin Dowex yang dielusi dengan larutan natrium klorida $1 \mathrm{M}$. Kandungan ekstrak kasar glikosaminoglikan dihitung berdasarkan bobot kering. Rendemen ekstrak kasar dari lambung adalah $65,93 \%$, usus $69,33 \%$, daging $44,08 \%$, dan insang $43,26 \%$. Sedangkan kandungan isolat murni glikosaminoglikan yang dihitung berdasarkan bobot kering dari masing-masing organ adalah lambung $58,53 \%$, usus $61,02 \%$, daging $33,77 \%$, dan insang $32,18 \%$. Hasil identifikasi menunjukkan bahwa isolat murni dari lambung mengandung senyawa glikosaminoglikan yang tak teridentifikasi. Sedangkan isolat murni dari usus, daging, dan insang mengandung keduanya yaitu senyawa khondroitin sulfat $C$ dan senyawa glikosaminoglikan yang tak teridentifikasi.
\end{abstract}

\section{ABSTRACT: Isolation and Characterization of Glycosaminoglycan Compound from Stingray (Trygon sephen) Organ. By : Thamrin Wikanta, Riyadini Perwita, Prih Sarnianto, and Murdinah.}

This paper reports the research on the isolation and characterization of glycosaminoglycan compound from stingray (Trygon sephen) organs that covered extracion process through digestion, precipitation and puritication and identification of the compound was done using infrared spectrophotometry, high performance liquid chromatography and electrophoresis. Extraction was carried out through enzymatic hydrolysis process by using $3 \%$ papain in phosphate buffer solution of $\mathrm{pH} 6.5$ at $65^{\circ} \mathrm{C}$ for 24 hours. Crude extract was obtained by digestion followed by precipitation process using technical grade alcohol and that ekstract was then purified through column chromatography using Dowex resin that was eluted by $1 \mathrm{M}$ sodium chloride solution. The contents of crude glycosaminoglycan extract from each organ calculated based on dry weight were stomach $65.93 \%$, intestine $69.33 \%$, flesh $44.08 \%$, and gills $43.26 \%$. Whilst the content of pure glycosaminoglycan isolate calculated based on dry weight were stomach $58.53 \%$, intestine $61.02 \%$, flesh $33.77 \%$, and gills $32.18 \%$. The results of identification showed that pure isolate from stomach contained unidentified glycosaminoglycan compound. Whilst pure isolate from intestine, flesh, and gills contained both chondroitin sulphate $C$ and unidentified glycosaminoglycan compound.

KEYWORDS: isolation, characterization, glycosaminoglycan, stingray fish organ.

\section{PENDAHULUAN}

Ikan pari tersebar hampir di seluruh perairan Indonesia, terutama di perairan Indonesia Bagian Barat dan Bagian Selatan, di sekitar Kalimantan, Sulawesi, Sumatera, dan Laut Jawa. Beberapa spesies ikan pari yang terdapat di Indonesia adalah: Trygon sephen, Rhinoptera javanica, Himantura signifer, dan Himantura chaophraya (Kottelat, 1986). Ikan pari dapat dikonsumsi dalam berbagai bentuk, di antaranya dalam bentuk

\footnotetext{
*) Peneliti pada Pusat Riset Pengolahan Produk dan Sosial Ekonomi Kelautan dan Perikanan

") Fakultas Farmasi Universitas Pancasila
} 
segar atau sebagai ikan asin. Kulit ikan pari dapat dibuat sebagai bahan kerajinan, seperti: tas dan sepatu. Sementara itu, organ ikan pari sering dimanfaatkan sebagai obat karena diketahui mengandung bermacammacam senyawa bioaktif, salah satunya adalah senyawa mukopolisakarida (glikosaminoglikan). Selama ini beberapa organ ikan pari dianggap sebagai limbah hasil pengolahan dan belum dimanfaatkan secara maksimal. Limbah ikan tersebut berupa ekor, insang, tulang, kepala, isi perut dan sebagainya yang mencapai $50 \%$ dari bobot total ikan. Berbagai upaya telah dilakukan untuk dapat memanfaatkan limbah tersebut agar memiliki nilai tambah yang jauh lebih tinggi.

Glikosaminoglikan adalah senyawa polisakarida yang merupakan polimer dari unit disakarida, yang tersusun dari monosakarida berbeda. Klasifikasi senyawa glikosaminoglikan lebih ditekankan kepada strukturnya yang seringkali didominasi oleh senyawa disakarida (Comper dan Laurent, 1978). Pada jaringan hewan golongan vertebrata dapat ditemukan tujuh jenis glikosaminoglikan dari molekul proteoglikan yang terikat kovalen pada protein dari proteoglikan (Kennedy dan White, 1990; Frisell, 1992).

Glikosaminoglikan atau disebut juga mukopolisakarida bersifat polianionik karena mempunyai gugus sulfat asam atau gugus karboksil dari asam uronat yang terdapat di seluruh struktur dan bersifat sangat hidrofilik. Banyak dari fungsi glikosaminoglikan ditentukan dari sifat khusus ini, seperti mengeluarkan molekul-molekul dari dalam sel dan memberikan fungsi spesifik dari ekstra sel (Kennedy dan White, 1990; Martin et al., 1984; Frisell, 1992). Glikosaminoglikan dapat berinteraksi dengan makromolekul ekstraseluler, protein plasma, komponen permukaan sel dan makromolekul intrasel. Selain itu, ikatan antara glikosaminoglikan dan makromolekul ekstrasel lain secara bermakna membantu organisasi struktural matriks jaringan penyambung. Ikatan ini umumnya bersifat elektrostatik karena sifat polianioniknya yang menonjol (Martin et al., 1984).

Glikosaminoglikandapat digunakan sebagai antikoagulan karena ia mengandung heparin yang mempercepat inaktivasi faktor pembekuan darah (Sulistia, 1995). Senyawa khondroitin yang terkandung di dalamnya dapat digunakan untuk mengobati penyakit katarak tingkat dini sebab dapat merobek selaput tipis yang menutupi kornea mata. Khondroitin juga digunakan sebagai obat anti penuaan sebab khondroitin dapat menjaga kelenturan organ tubuh, menjaga tegangan permukaan dan menahan cairan tubuh (Suparno, 1996).

Glikosaminoglikan diperoleh sebagai hasil ekstraksi dari limbah ikan jenis elasmobranchii, di antaranya ikan cucut dan ikan pari. Dalam pengolahan ikan pari umumnya hanya bagian daging dan kulit yang dimanfaatkan, sedangkan sisanya dibuang. Padahal limbah tersebut terutama bagian organ dalam ikan, seperti: lambung, usus, limpa, dan insang diperkirakan sebagai sumber utama glikosaminoglikan.

Pada tulisan ini disajikan hasil penelitian tentang ekstraksi dan isolasi senyawa glikosaminoglikan dari organ ikan pari (daging, lambung, usus, dan insang) serta karakterisasi senyawa yang didapatkan. Organ ikan pari yang selama ini belum dimanfaatkan secara maksimal diharapkan akan dapat dimanfaatkan dan memberikan nilai tambah terhadap limbah tersebut, karena teknik ekstraksi glikosaminoglikan yang relatif sederhana telah dikembangkan (Suparno et al., 1998).

\section{BAHAN DAN METODE}

\section{Bahan}

- Bahan penelitian yang digunakan adalah tiga ekor ikan pari (Trygon sephen), masing-masing berukuran kecil (bobot 7 $\mathrm{kg})$, sedang $(13,5 \mathrm{~kg})$, dan besar $(17 \mathrm{~kg})$, diperoleh dari Tempat Pelelangan Ikan di Pelabuhan Ratu. Bagian tubuh ikan yang diteliti adalah lambung, usus, daging, dan insang.

- Standar glikosaminoglikan yang digunakan adalah Heparin (Sigma 9041-08-1); khondroitin A (Sigma 39455-18-0; mengandung khondroitin A $70 \%$ dan khondroitin C 30\%); Khondroitin C (Sigma 12678-07-8; mengandung khondroitin $C$ $90 \%$ dan khondroitin A $10 \%$ ).

\section{Metode}

1. Pengambilan dan penyiapan sampel

- Sebanyak tiga ekor ikan pari yang diperoleh dari Tempat Pelelangan Ikan di Pelabuhan Ratu, diperiksa ciri- 
cirinya, ditimbang dan diukur panjang dan bobotnya.

- Dari ketiga ekor ikan pari tersebut, masing-masing diambil lambung, usus, daging, dan insangnya.

- Organ tersebut dipisahkan dari organ yang lain, dicuci bersih dengan air, lalu dimasukkan ke dalam kantong plastik dan disimpan pada suhu $-10^{\circ} \mathrm{C}$. Saat akan digunakan dalam percobaan, diambil secukupnya lalu dicincang sampai halus.

2. Ekstraksi dan Pemurnian

Ekstraksi dan pemurnian senyawa glikosaminoglikan dilakukan dengan menggunakan metoda yang dikembangkan oleh Suparno et al. (1998). Ke dalam sampel ditambahkan larutan natrium etilen diamin tetra asetat $5 \%$, lalu dihidrolisis menggunakan enzim papain $3 \%$ dalam buffer fosfat $\mathrm{pH} 6,5$ selama 24 jam pada suhu $65^{\circ} \mathrm{C}$, kemudian dipresipitasi dengan alkohol teknis. Pemurnian dilakukan kopi Inframerah (Nakanishi, 1987; Fessenden dan Fessenden, 1997), Khromatografi Cair Kinerja Tinggi (Gritter et al., 1991; Johnson dan Stevenson, 1991), dan Elektroforesis (Hannig dan Pascher, 1969).

\section{HASIL DAN PEMBAHASAN}

\section{Karakterisasi Sampel}

Data hasil pengamatan karakteristik sampel ikan pari dapat dilihat pada Tabel 1 .

Proporsi lambung, usus, daging, dan insang ternyata cukup banyak (berkisar $18,5-23,5 \%)$, sehingga dapat digunakan sebagai sumber senyawa bioaktif untuk kebutuhan industri farmasi. Senyawa bioaktif glikosaminoglikan tersebar dalam setiap jaringan. Bila limbah ikan pari (di samping kulit dan daging) yang mencapai $50-55 \%$ dari bobot total ikan pari dapat dimanfaatkan, maka akan merupakan

Tabel 1. Karakteristik ikan pari (Trygon sephen).

Table 1. Characteristics of Stingray (Trygon sephen).

\begin{tabular}{lccc}
\hline \multirow{2}{*}{$\begin{array}{c}\text { Karakteristik } \\
\text { Characteristics }\end{array}$} & \multicolumn{3}{c}{ Ukuran Ikan/Size of Fish } \\
\cline { 2 - 4 } & Kecil/Small & Sedang/Medium & Besar/Big \\
\hline Bobot/Weight (kg) & 7 & 13,5 & 17 \\
Panjang/Length (cm) & 55 & 60 & 69 \\
Lebar/Width (cm) & 60 & 64 & 70 \\
Daging/Flesh (\%) & 17,14 & 15,56 & 21,18 \\
Tl. kepala/Head bone (\%) & 4,14 & 2,44 & 3,12 \\
TI. punggung/Backbone (\%) & 0,63 & 0,42 & 0,36 \\
Tl. ekor/Tail bone (\%) & 1,86 & 1,00 & 1,12 \\
TI. sayap/Wings bone (\%) & 13,43 & 7,19 & 6,47 \\
Otak/Brain (\%) & 0,33 & 0,15 & 0,13 \\
Insang/Gills (\%) & 2,05 & 1,66 & 1,39 \\
Lambung/Stomach (\%) & 0,53 & 0,70 & 0,45 \\
Usus//ntestine (\%) & 0,69 & 0,63 & 0,44 \\
Kulit/Skin (\%) & 12,71 & 6,63 & 7,06 \\
Mata/Eyes (\%) & 0,18 & 0,09 & 0,17 \\
\hline
\end{tabular}

secara khromatografi penukar ion menggunakan resin Dowex dengan larutan natrium khlorida $1 \mathrm{M}$ sebagai cairan pengelusi.

3. Analisis

Analisis yang dilakukan terhadap bahan mentah dan produk glikosaminoglikan adalah:
a. Analisis Kadar Air (AOAC, 1980).
b. Analisis Kadar Abu (AOAC, 1980).
c. Karakterisasi Senyawa Glikosaminog-
likan menggunakan metoda Spektros-

sumber senyawa bioaktif yang sangat potensial untuk dapat dikembangkan.

\section{Kadar Air dan Kadar Abu Bahan Baku}

Kadar air dan abu bahan baku dari organ lambung, usus, daging, dan insang ikan pari (Trygon sephen) dapat dilihat pada Tabel 2. Kadar air bahan baku berkisar antara 79,61$89,04 \%$. Hasil pengukuran kadar air organ ikan pari menunjukkan bahwa kadar air sampel dari masing-masing organ (lambung, usus, daging, dan insang) relatif tinggi dan 
Tabel 2. Kadar air dan kadar abu bahan baku dari lambung, usus, daging, dan insang ikan pari (Trygon sephen).

Table 2. Moisture and ash contents of raw material from the stomach, intestine, flesh, and gills of Stingray (Trygon sephen)

\begin{tabular}{cccc}
\hline $\begin{array}{c}\text { Sampel } \\
\text { Sample }\end{array}$ & $\begin{array}{c}\text { Ukuran Ikan } \\
\text { Size of Fish }\end{array}$ & $\begin{array}{c}\text { Kadar Air } \\
\text { Moisture } \\
(\%)\end{array}$ & $\begin{array}{c}\text { Kadar Abu } \\
\text { Ash Content } \\
\text { (\%) }\end{array}$ \\
\hline Lambung & Kecil/Small & 88,93 & 0,43 \\
Stomach & Sedang/Medium & 85,59 & 0,89 \\
& Besar/Big & 85,43 & 0,67 \\
Usus & Kecil/Small & 89,04 & 0,23 \\
Intestine & Sedan/Medium & 84,83 & 0,55 \\
& Besar/Big & 79,61 & 0,62 \\
Daging & Kecil/Small & 85,19 & 1,36 \\
Flesh & Sedang/Medium & 83,78 & 0,85 \\
Insang & Besar/Big & 82,94 & 0,80 \\
Gills & Kecil/Small & 83,37 & 2,35 \\
\hline
\end{tabular}

Tabel 3. Kadar air ekstrak kasar dan isolat murni dari lambung, usus, daging, dan insang ikan pari (Trygon sephen).

Table 3. Moisture of crude glycosaminogycan extract and pure isolate from the stomach, intestine, flesh, and gill of Stingray (Trygon sephen)

\begin{tabular}{cccc}
\hline Sampel & Ukuran Ikan & \multicolumn{2}{c}{ Kadar Air (\%)/Moisture (\%) } \\
\cline { 3 - 4 } Sample & Size of Fish & $\begin{array}{c}\text { Ekstrak Kasar } \\
\text { Crude Extract }\end{array}$ & $\begin{array}{c}\text { Isolat Murni } \\
\text { Pure Isolate }\end{array}$ \\
\hline Lambung & Kecil/Small & 88,93 & 0,43 \\
Stomach & Sedang/Medium & 85,59 & 0,89 \\
& Besar/Big & 85,43 & 0,67 \\
Usus & Kecil/Small & 89,04 & 0,23 \\
Intestine & Sedang/Medium & 84,83 & 0,55 \\
& Besar/Big & 79,61 & 0,62 \\
Daging & Kecil/Small & 85,19 & 1,36 \\
Flesh & Sedang/Medium & 83,78 & 0,85 \\
& Besar/Big & 82,94 & 0,80 \\
Insang & Kecil/Small & 83,37 & 2,35 \\
Gills & Sedang/Medium & 85,44 & 2,14 \\
& Besar/Big & 82,32 & 2,84 \\
\hline
\end{tabular}

perbedaannya tidak terlalu besar. Hal ini menunjukkan bahwa air merupakan komponen dasar dari ikan dan air tersebar merata dalam setiap organ ikan.

Kadar abu ikan pari perlu diukur untuk mengetahui dengan pasti kandungan senyawa anorganik atau mineral yang terdapat pada ikan pari. Kadar abu lambung, usus, dan daging sangat rendah, yaitu kurang dari $1 \%$ (kecuali dari ikan pari nomor 1 yaitu $1,36 \%)$, sedangkan kadar abu pada insang cukup tinggi $(2,14-2,84 \%)$. Hasil analisis tersebut menunjukkan bahwa komponen utama dari sampel organ ikan pari tersebut adalah air dan zat organik.

\section{Ekstrak Kasar Glikosaminoglikan}

Data hasil ekstraksi glikosaminoglikan dari masing-masing organ lambung, usus, daging, dan insang ikan pari (Trygon sephen) dapat dilihat pada Tabel 3. Kadar air ekstrak kasar berkisar antara $37,82-50,10 \%$, dan kadar air isolat murni berkisar antara 37,51-50,16\%. Ekstrak kasar dan isolat murni adalah senyawa glikosaminoglikan, berupa senyawa karbohidrat yang bersifat higroskopis di udara terbuka dan bersifat polianionik di dalam air. Kadar air ekstrak cukup tinggi walaupun telah dikeringkan dalam desikator. Para ahli mengemukakan bahwa glikosaminoglikan terdistribusi dalam dinding sel hewan, biasanya berikatan dengan protein membentuk proteoglikan. Kandungan glikosaminoglikan dalam proteoglikan bervariasi antara $50-95 \%$ dari bobot total proteoglikan, dan sisanya adalah protein dan polisakarida lain. Oleh karena itu sifat-sifat glikosaminoglikan 
mendominasi atau menentukan sifat proteoglikan (Hook et al., 1984; Hassell et al., 1986; Kennedy dan White, 1990). Proteoglikan ditemukan di dalam senyawa basalis, bersifat seperti gel atau perekat antar sel yang mengisi ruangan antara sel pada kebanyakan jaringan (Lehninger, 1990).

Ekstrak kasar yang diperoleh adalah glikosaminoglikan yang mengandung sedikit protein. Ekstrak kasar tersebut bersifat polianionik, dalam bentuk garam natrium dan sangat mudah larut di dalam air. Rendemen ekstrak kasar dinyatakan dalam bobot kering dapat dilihat pada Tabel 4. Hasil penelitian

\section{Isolat Murni Glikosaminoglikan}

Hasil pemurnian ekstrak kasar glikosaminoglikan dari lambung, usus, daging, dan insang ikan pari (Trygon sephen) dapat dilihat pada Tabel 4. Untuk tiap isolat murni digunakan masing-masing satu ekstrak kasar yang dianggap paling baik dari organ lambung, usus, daging, dan insang. Pemilihan isolat murni yang paling baik berdasarkan ekstrak kasar dengan rendemen paling tinggi dan warnanya paling putih. Hal ini berdasarkan asumsi bahwa makin tinggi rendemen ekstrak kasarnya makin tinggi kandungan

Tabel 4. Rendemen ekstrak kasar dan isolat murni glikosaminoglikan dari lambung, usus, daging dan insang ikan pari (Trygon sephen) berdasarkan bobot kering.

Table 4. The yield of crude glycosaminoglycan extract and pure isolate from the stomach, intestine, flesh, and gills of Stingray (Trygon sephen) based on dry weight

\begin{tabular}{cccc}
\hline Sampel & Ukuran Ikan & \multicolumn{2}{c}{ Kadar Air (\%)/Moisture (\%) } \\
\cline { 3 - 4 } Sample & Size of Fish & $\begin{array}{c}\text { Ekstrak Kasar } \\
\text { Crude Extract }\end{array}$ & $\begin{array}{c}\text { Isolat Murni } \\
\text { Pure Isolate }\end{array}$ \\
\hline Lambung & Kecil/Small & 59,95 & 56,41 \\
Stomach & Sedang/Medium & 66,18 & 54,96 \\
& Besar/Big & 76,69 & 62,22 \\
Usus & Kecil/Small & 81,99 & 64,45 \\
Intestine & Sedang/Medium & 78,87 & 66,42 \\
& Besar/Big & 57,47 & 52,19 \\
Daging & Kecil/Small & 41,57 & 35,15 \\
Flesh & Sedang/Medium & 52,90 & 29,89 \\
& Besar/Big & 54,94 & 36,28 \\
Insang & Kecil/Small & 42,73 & 42,38 \\
Gills & Sedang/Medium & 43,48 & 21,91 \\
& Besar/Big & 43,20 & 32,25 \\
\hline
\end{tabular}

menunjukkan bahwa perhitungan rendemen ekstrak kasar berdasarkan bobot kering memberikan hasil yang relatif tinggi; hal ini membuktikan bahwa air berpengaruh terhadap hasil ekstrak kasar yang diperoleh. Ekstrak kasar glikosaminoglikan bersifat sangat higroskopis sehingga harus diperhatikan dalam penyimpanan dan pemakaiannya, khususnya untuk sediaan farmasi karena dapat merusak stabilitas glikosaminoglikan yang dapat berpengaruh terhadap aktivitasnya. Rendemen ekstrak kasar menunjukkan bahwa usus menghasilkan ekstrak kasar (rata-rata 69,33\%) lebih banyak dari pada lambung (rata-rata 65,93\%), daging (rata-rata $44,08 \%$ ) dan insang (rata-rata 43,26\%). Kandungan glikosaminoglikan yang tinggi pada organ dalam ikan pari (usus dan lambung) diduga karena peranannya sangat besar dalam proses fisiologis dalam organ tubuh. senyawa glikosaminoglikannya, dan makin putih warna isolat murninya makin sedikit zat pengotornya.

Pemurnian ekstrak kasar glikosaminoglikan menggunakan teknik khromatografi kolom dengan resin Dowex menghasilkan isolat glikosaminoglikan dengan kemurnian sangat tinggi, hal ini terlihat dari warnanya yang relatif jauh lebih putih. Rendemen rata-rata isolat murni berdasarkan bobot kering dari lambung adalah $58,53 \%$, usus $61,02 \%$, daging $33,77 \%$, dan insang $32,18 \%$; hal ini menunjukkan kandungannya yang tinggi.

\section{Identifikasi Senyawa dari Isolat Murni}

Identifikasi senyawa glikosaminoglikan isolat murni dari organ lambung, usus, daging, dan insang, dilakukan secara spektrofotometri inframerah, khromatografi cair kinerja tinggi (KCKT), dan elektroforesis. 


\section{Secara Spektrofotometri Inframerah}

Spektrum inframerah standar heparin, standar khondroitin sulfat $C$, dan isolat glikosaminoglikan dari organ lambung, usus, daging, dan insang ikan pari (Trygon sephen) masing-masing terlihat pada Gambar 1, 2, 3, 4, 5 dan 6. Spektrum inframerah senyawa standar heparin dan standar khondroitin sulfat C memberikan puncak-puncak absorpsi dengan bilangan gelombang sebagai berikut: gugus $-\mathrm{SO}_{3} \mathrm{H}$ pada $960-1050 \mathrm{~cm}^{-1}$; gugus $\mathrm{C}-\mathrm{N}$ dan $-\mathrm{OH}$ pada $1220-1240 \mathrm{~cm}^{-1}$; gugus $\mathrm{C}-\mathrm{H}$ dan $\mathrm{C}=\mathrm{O}$ pada $1400-1430 \mathrm{~cm}^{-1}$; gugus $\mathrm{N}-\mathrm{H}$ dan $\mathrm{C}=\mathrm{O}$ pada $1600-1690 \mathrm{~cm}^{-1}$; gugus $-\mathrm{OH}$ dan $\mathrm{N}-\mathrm{H}$ pada $3400 \mathrm{~cm}^{-1}$. Spektrum inframerah kedua senyawa standar heparin dan khondroitin sulfat tersebut tampak sama karena gugus fungsional yang terdapat pada keduanya sama, hanya berbeda pada posisi terikatnya gugus fungsional di dalam struktur senyawa tersebut. Pada Gambar 3, 4, 5 dan 6 terlihat spektrum inframerah isolat murni dari lambung, usus, daging, dan insang yang memberikan puncak absorpsi yang sama pada bilangan gelombang berikut: 960-1050

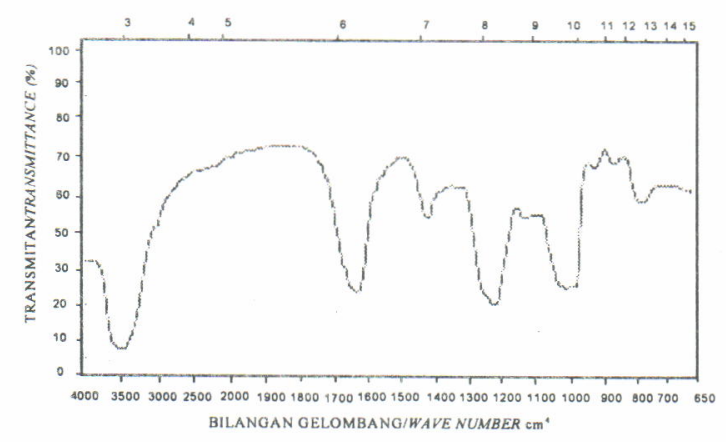

Gambar 1. Spektrum inframerah standar herapin Figure 1. Infrared spectrum of heparin standard

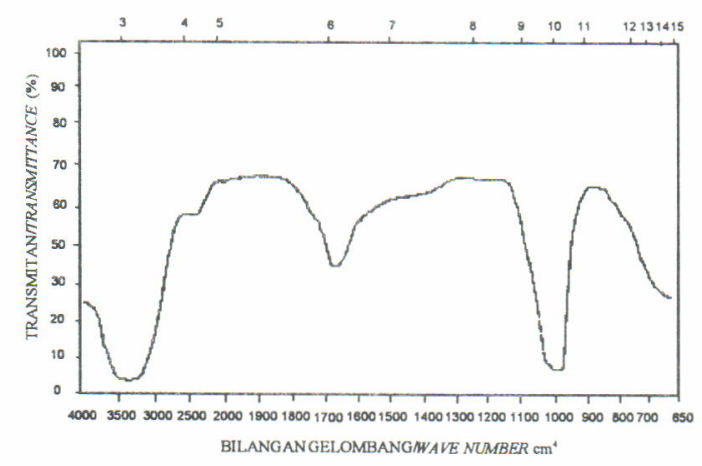

Gambar 3. Spektrum inframerah isolat murni glikosaminoglikan dari organ lambung ikan pari (Trygon sephen)

Figure 3. Infared spectrum of glycosaminoglycan isolated from stomach organ of stingray fish (Trygon sephen) $\mathrm{cm}^{-1}$ adanya gugus $-\mathrm{SO}_{3} \mathrm{H} ; 1600-1690 \mathrm{~cm}^{-1}$ adanya gugus $\mathrm{N}-\mathrm{H}$ dan $\mathrm{C}=\mathrm{O} ; 3200-3400 \mathrm{~cm}^{-1}$ adanya gugus $\mathrm{OH}$ dan $\mathrm{N}-\mathrm{H}$. Spektrum inframerah yang diperoleh dari isolat murni tidak memberikan puncak absorpsi yang tajam, diduga hal ini karena adanya kandungan air dalam ekstrak murni sehingga menjadi lembab yang dapat mempengaruhi pengukuran. Setelah dibandingkan dengan zat standar ternyata isolat murni memberikan puncak absorpsi yang berbeda dari khondroitin sulfat $C$ dan heparin standar. Terdapat beberapa puncak absorpsi seperti pada bilangan gelombang $1210-1240 \mathrm{~cm}^{-1}$ dan 1400-1430 $\mathrm{cm}^{-1}$ dari spektrum standar tidak terdeteksi pada spektrum isolat, tetapi gugus-gugus fungsional yang penting seperti $\mathrm{SO}_{3} \mathrm{H}, \mathrm{N}-\mathrm{H}, \mathrm{C}=\mathrm{O}$, dan $\mathrm{OH}$ tampak pada spektrum isolat murni. Dapat disimpulkan bahwa isolat murni tersebut merupakan senyawa glikosaminoglikan tetapi tidak dapat dipisahkan atas jenis-jenis atau komponenkomponennya karena spektrum inframerah hanya memberikan petunjuk tentang gugus fungsional yang sama yang terdapat pada setiap isolat murni.

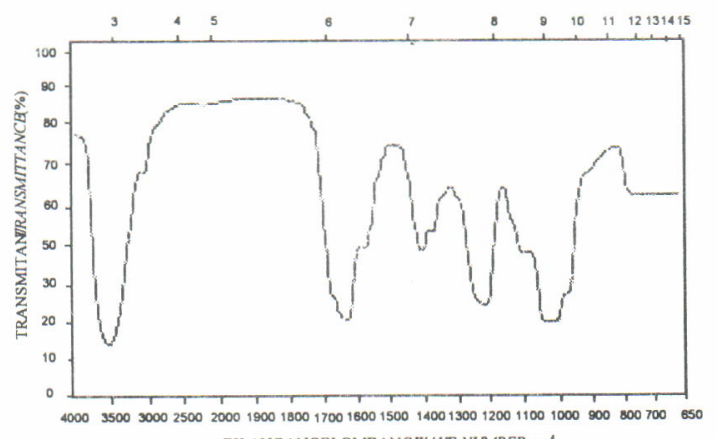

BILANGANGELOMBANGWAVE NUMBER $\mathrm{cm}^{4}$

Gambar 2. Spektrum inframerah standar khondrohitin sulfat $C$

Figure 2. Infrared spectrum of chondroitin sulfhate $C$ standard

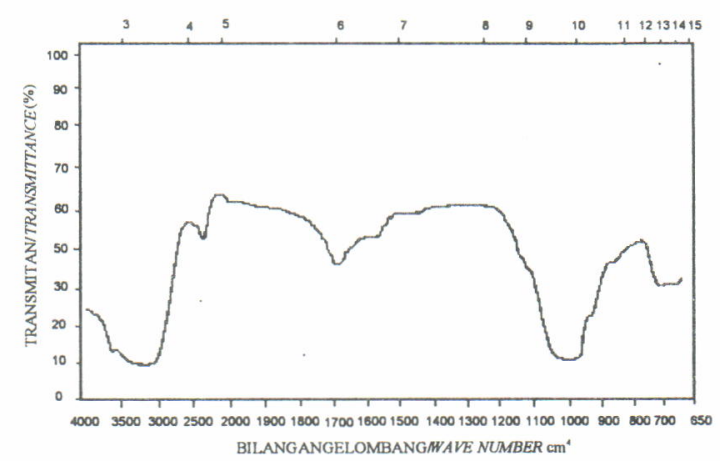

Gambar 4. Spektrum inframerah isolat murni glikosaminoglikan dari organ usus ikan pari (Trygon sephen)

Figure 4. Infared spectrum of glycosaminoglycan isolated from intestin oraan of stinarav 


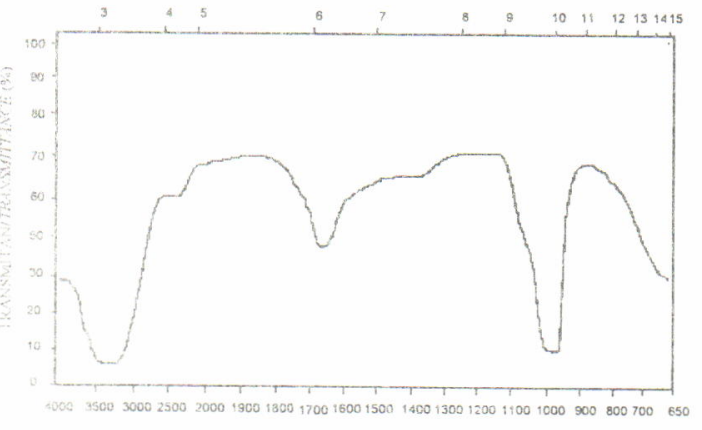

BLLANGANGLIOMBANGWAEE NIAABER $\mathrm{cm}^{4}$

Gambar 5. Spektrum inframerah isolat murni glikosaminoglikan dari organ daging ikan pari (Trygon sephen)

Figure 5. Infared spectrum of glycosaminoglycan isolated from flesh of stingray fish (Truaon seohen!

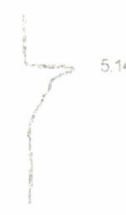

$\begin{array}{cccccc}\text { No WAKTURETENST } & \text { AREA } & 1000 \text { KONSENTRASI } & \text { BC } & \text { O8/10199 09:08 } \\ 1 & 5.14 & 78848 & 100.000 & B 8 & \\ \text { TOTEL } & 78848 & 100.000 & & \\ \text { PEAK FES } 10.000 & & & \end{array}$

Gambar 7. Kromatogram KCKT standar heparin

Figure 7. HPLC chromatogram of heparin standar

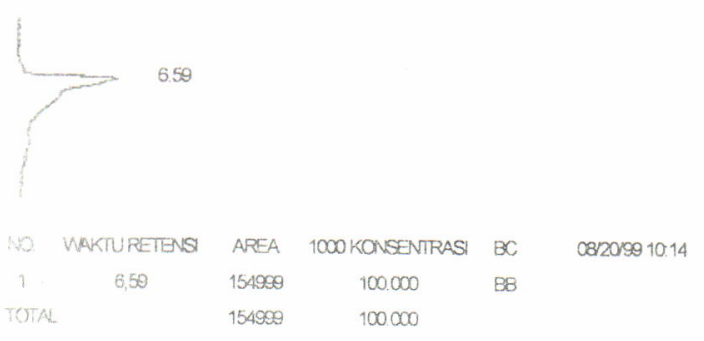

PEAKREE: 10000

Gambar 9. Kromatogram KCKT isolat murni glikosaminoglikan dari organ lambung ikan pari (Trygon sephen)

Figure 9. HPLC chromatogram of glycosaminoglycan isolated from stomach organ of stingray fish (Trygon sephers)

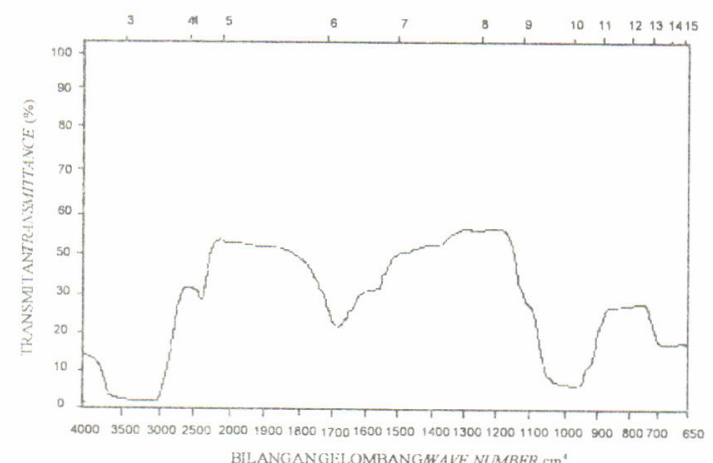

BILANGANGELOMBANG WAVE NUMBER $\mathrm{cm}$

Gambar6. Spektrum inframerah isolat murn glikosaminoglikan dari organ insang ikan pari (Trygon sephen)

Figure 6. Infared spectrum of glycosaminoglycan isolated from gills organ of stingray fish (Trygon sephen)

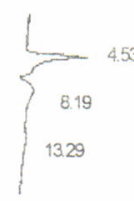

\begin{tabular}{|c|c|c|c|c|c|}
\hline NO & WAKTURETES & AREA & 1000 KONSENIRAS & $\mathrm{BC}$ & $08209911: 29$ \\
\hline 1 & 4,53 & 52394 & 76.383 & $B 8$ & \\
\hline 2 & 8,19 & 16199 & 23616 & 38 & \\
\hline TOI & & 68593 & 100.000 & & \\
\hline
\end{tabular}

PEAKREJ: 10.000

Gambar 8. Kromatogram KCKT standar khondrohitin sulfat $\mathrm{C}$

Figure 8. HPLC chromatogram of chondroitin sulphate C standard

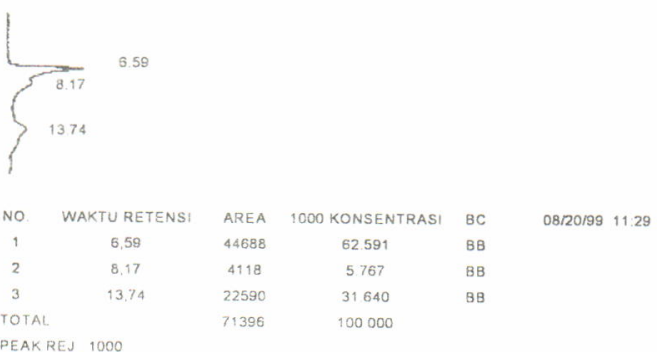

EAR REJ 1000

Gambar 10. Kromatogram KCKT isolat murni glikosaminoglikan dari organ usus ikan pari (Trygon sephen).

Figure 10. HPLC chromatogram of glycosaminoglycan isolated from intestine organ of stingray fish (Trygon sephen) 


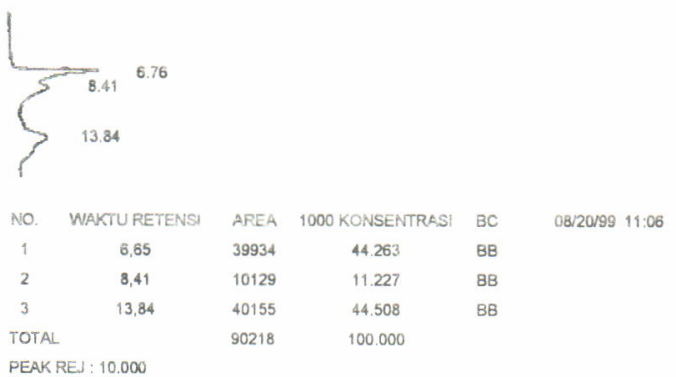

Gambar 11. Kromatogram KCKT isolat murni glikosaminoglikan dari organ daging ikan pari (Trygon sephen).

Figure 11. HPLC chromatogram of glycosaminoglycan isolated from intestine organ of stingray fish (Trygon sephen)

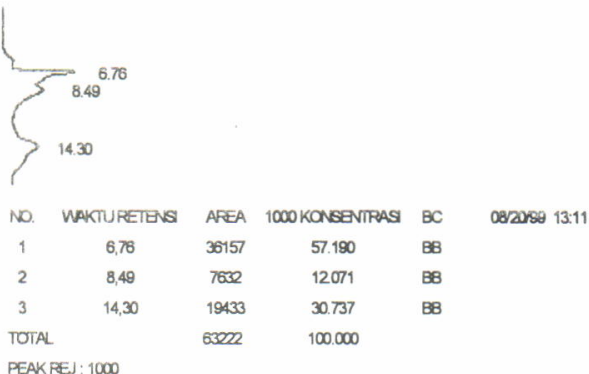

Gambar 12. Kromatogram KCKT isolat murni glikosaminoglikan dari organ insang ikan pari (Trygon sephen).

Figure 12. HPLC chromatogram of glycosaminoglycan isolated from intestine organ of stingray fish (Trygon sephen)

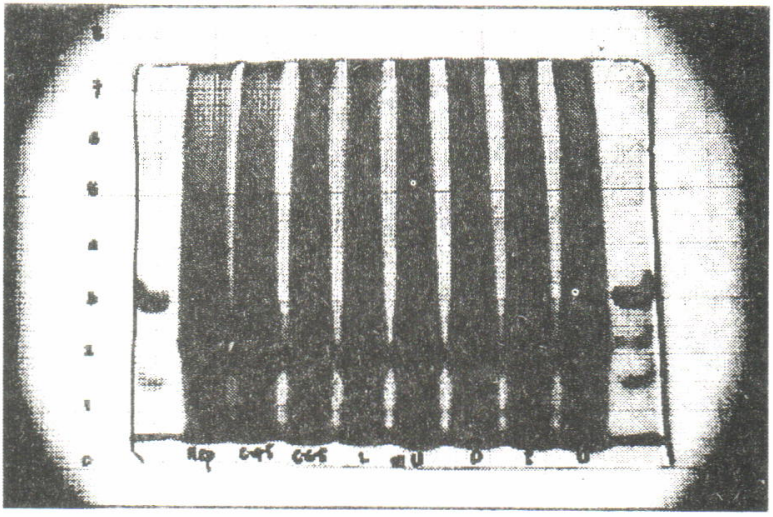

Gambar 13. Hasil pemisahan standar dan isolat murni glikosaminoglikan dari organ ikan pari (Trygon sephen) secara elektroforesis dalam buffer tris-gliserol. Hep = heparin; c-4-s = khondroitin 4-sulfat; c-6-s = khondroitin 6-sulfat; $L=$ lambung; $U=$ usus; $D=$ daging; I = insang;

Figure 13. Electrophoretic separation of glycosaminoglycan standard and isolated from stingray fish organ (Trygon sephen) in the tris-glycerol buffer solution. HCP = heparin; c-4-s = chondrohitin sulphate-4; c-6-s= chondrohitin sulphate-6, $L=$ stomach; $U$ = intestine; $D=$ flesh; $I=$ gills

\section{Secara Kromatografi Cair Kinerja Tinggi} (KCKT)

Hasil identifikasi dengan metoda KCKT terhadap standar heparin, standar khondroitin sulfat C dan isolat glikosaminoglikan dari organ lambung, usus, daging, dan insang ikan pari (Trygon sephen) terlihat pada Gambar 7 , $8,9,10,11$, dan 12. Tampak pada spektrum absorpsi bahwa standar heparin (Gambar 7) memiliki satu puncak pada waktu retensi 5,14 menit dan standar khondroitin sulfat $C$ (Gambar 8) memiliki dua puncak pada waktu retensi 4,53 dan 8,19 menit. Sedangkan isolat murni dari lambung (Gambar 9) memiliki satu puncak dengan waktu retensi 6,59 menit; dari usus (Gambar 10) memiliki tiga puncak dengan waktu retensi 6,$59 ; 8,17$; dan 13,74 menit; dari daging (Gambar 11) memiliki tiga puncak dengan waktu retensi 6,$65 ; 8,41$; dan
13,84 menit; dan dari insang (Gambar 12) memiliki tiga puncak dengan waktu retensi 6,$76 ; 8,49$; dan 14,30 menit.

Hasil analisis dan identifikasi terhadap khromatogram isolat murni dari lambung (Gambar 9) dengan membandingkannya terhadap kromatogram standar heparin (Gambar 7) dan khondroitin sulfat C (Gambar 8) menunjukkan bahwa tidak ada puncak absorpsi yang memiliki waktu retensi yang sama atau berdekatan sehingga dapat disimpulkan bahwa ditinjau dari waktu retensi senyawa glikosaminoglikan maka isolat dari lambung tidak mengandung heparin atau khondroitin sulfat $C$ tetapi mungkin mengandung jenis glikosaminoglikan yang lain yang berbeda dalam ukuran bobot molekulnya.

Membandingkan antara kromatogram isolat 
murni dari usus (Gambar 10), daging (Gambar 11) dan insang (Gambar 12) terhadap kromatogram standar heparin (Gambar 7) dan khondroitin sulfat C (Gambar 8) menunjukkan adanya kesamaan atau mendekati nilai waktu retensi antara isolat murni dengan zat standar khondroitin sulfat $C$, yaitu pada waktu retensi 8,17 menit (usus), 8,41 menit (daging), dan 8,49 menit (insang), tetapi tidak ada kesamaan dengan heparin. Hal ini menyimpulkan bahwa ditinjau dari waktu retensi senyawa glikosaminoglikan maka isolat dari usus, daging dan insang mengandung khondroitin sulfat $\mathrm{C}$ dan tidak mengandung heparin, tetapi mungkin mengandung jenis senyawa glikosaminoglikan yang lain dengan ukuran bobot molekul berbeda. Karena terbatasnya standar glikosaminoglikan yang tersedia maka tidak dapat dilakukan identifikasi lebih lanjut untuk dapat mengungkap jenis glikosaminoglikan yang terkandung di dalam isolat yang sudah didapat tersebut. Suatu kemungkinan lain adalah bahwa jenis glikosaminoglikan tersebut sama tetapi dengan ukuran bobot molekul yang berbeda, sebagaimana dikemukakan oleh Hassel et al.(1986) bahwa senyawa glikosaminoglikan yang terdapat di dalam jaringan sangat beragam dengan bobot molekul berkisar antara 40.000-60.000.

\section{Secara Elektroforesis}

Analisis kualitatif secara elektroforesis terhadap standar heparin, khondroitin sulfat $A$, khondroitin sulfat $\mathrm{C}$ dan isolat murni dari lambung, usus, daging, dan insang ikan pari (Trygon sephen) dapat dilihat pada Gambar 13. Tampak bahwa semua noda sampel memberikan pola migrasi yang sama dengan zat standar yang didominasi oleh noda yang memiliki $\mathrm{Rf}+1,8 \mathrm{~cm}$. Pada noda sampel khondroitin 6-sulfat (C-6-S), lambung (L), usus $(U)$, daging $(D)$, dan insang $(I)$ terlihat ada noda dengan $R f \pm 5 \mathrm{~cm}$. Diduga adanya fraksi glikosaminoglikan yang memiliki bobot molekul kecil atau muatan yang lebih besar dari pada noda utama, tetapi dengan kadar yang relatif sangat sedikit. Pada standar heparin dan khondroitin 4-sulfat (C-4-S), noda dengan $\mathrm{Rf} \pm 5 \mathrm{~cm}$ tak terlihat, berarti fraksi kecil tersebut tidak terdapat di dalamnya. Disamping itu, juga terdapat fraksi dengan bobot molekul besar atau muatan yang lebih kecil dari pada noda utama dengan $\mathrm{Rf} \pm 1 \mathrm{~cm}$, yang terdapat pada semua noda sampel dan standar, berarti terdapat fraksi kecil di dalamnya.

Identifikasi isolat secara elektroforesis seperti terlihat pada Gambar 13 menunjukkan terjadinya pemisahan atas beberapa jenis senyawa glikosaminoglikan. Tiap isolat terpisah relatif sama menjadi tiga fraksi dengan nilai Rf yang sama. Salah satu fraksi dari keempat isolat menunjukkan adanya senyawa khondroitin sulfat, terlihat dari nilai $\mathrm{Rf}$ yang sama antara fraksi-fraksi isolat dan standar sama dengan nilai $\mathrm{Rf}$ khondroitin sulfat standar dan isolat, tetapi dapat disimpulkan bahwa isolat tidak mengandung heparin karena pada saat identifikasi dengan metoda KCKT terbukti isolat tidak mengandung heparin.

Pada nilai Rf yang sama $( \pm 1 \mathrm{~cm}$ dan \pm 5 $\mathrm{cm}$ ) dari fraksi isolat tampak adanya noda yang menunjukkan jenis glikosaminoglikan yang lain tetapi belum dapat diidentifikasi karena terbatasnya senyawa glikosaminoglikan standar yang tersedia. Suatu kemungkinan lain adalah bahwa senyawa tersebut sama dengan senyawa utama tetapi dengan bobot molekul yang berbeda.

\section{KESIMPULAN}

Hasil isolasi dan identifikasi senyawa glikosaminoglikan dari organ ikan pari (Trygon sephen) dapat disimpulkan sebagai berikut:

1. Perhitungan rendemen isolat murni berdasarkan bobot basah untuk lambung adalah $13,95 \%$, usus $16,18 \%$, daging $9,93 \%$, dan insang $8,56 \%$; sedangkan rendemen isolat murni berdasarkan bobot kering untuk lambung adalah $58,53 \%$, usus $61,02 \%$, daging $33,77 \%$, dan insang $32,18 \%$. Hasil penelitian menunjukkan bahwa senyawa glikosaminoglikan paling banyak terdapat pada usus diikuti oleh lambung, daging, dan insang.

2. Hasil identifikasi menunjukkan bahwa isolat dari lambung mengandung senyawa golongan glikosaminoglikan. Sedangkan fraksi isolat yang terkandung di dalam glikosaminoglikan dari usus, daging, dan insang di antaranya adalah khondroitin sulfat C dan jenis senyawa glikosaminoglikan yang lain yang belum teridentifikasi.

\section{DAFTAR PUSTAKA}

AOAC. 1980. Official Methods of Analysis of the 
Association of Official Analytical Chemists. Ed 13. AOAC, Washington. $211 \mathrm{p}$.

Comper, W.D. and Laurent, T.C. 1978. Physiological Function of Connective Tissue Polysaccharides. Vol. 58. Institute of Medical and Physiological Chemistry Univ. of Uppsala. p. $60-75$

Fessenden, R.J. dan Fessenden, J.S. 1997. Kimia Organik. Spektroskopi I: Inframerah dan Resonansi Magnetik Nuklir (NMR). Jilid I. Ed. 3. Alih bahasa: A.H. Pudjaatmaka. Penerbit Erlangga, Jakarta. p. 311-375.

Frisell, W.R. 1992. Human Biochemistry. Mc Millan Publishing Co., Inc., New York. p. 139-149.

Gritter, R.J., Bobbitt, J.M. dan Schwarting, A.E. 1991. Pengantar Kromatografi. Ed. 2. Penerjemah: K. Padmawinata. Penerbit ITB, Bandung. 266p.

Hannig, K. dan Pascher, G. 1969. Thin-Layer Electrophoresis. In Stahl, E. (Ed.). Thin-Layer Chromatography. A Laboratory Handbook. Topan Co. L.td., Tokyo. p. 105-114.

Hassell, J.R., Kimura, J.H., and Hascall, V.C., 1986. Proteoglycan Core Protein Families. In Richarden, C.C., Boyer, P.D., Dawid, I.B. dan Meister, A. (eds.). Ann. Rev. Biochemistry. 55: 539-567.

Hook, M., Kejellen, L.S., Johanson, S. and Robinson, J. 1984. Cell Surface
Glycosaminoglycan, Ann. Rev. Biochem. 53: 847-867

Johnson, E.L. dan Stevenson, R. 1991. Dasar Kromatografi Cair. Penterjemah: Padmawinata, K. Penerbit ITB, Bandung. $365 \mathrm{p}$.

Kennedy, J.F. and White, C.A. 1990. The Glycosaminoglycans and Proteoglycans. In Kenedy, J.F. (ed.). Carbohydrate Chemistry. Claredon, Oxford. p. 303-341.

Kottelat, M., 1986. Ikan Tawar Indonesia Bagian Barat dan Sulawesi. Alih bahasa: Kartikasari, S. N.. Tiara, Jakarta. p. 2-4.

Lehninger, A.L., 1990. Dasar-dasar Biokimia. Alih bahasa: Thenawidjaja, M. Erlangga, Jakarta. p. 333-335.

Martin, D.W., Mayes, P.A., dan Rodwell, V.W., 1984. Harpers Review of Biochemistry. Lange Medical Publication, California. p. 515-528.

Nakanishi, K., 1987. Infrared Absorption Spectroscopy. Holden-Day, Inc., San Fransisco. p. 1-5.

Sulistia, G.G., 1995. Farmakologi dan Terapi. Ed. 4. Bagian Farmakologi FKUI, Jakarta. p. 686701

Suparno, 1996. Ikan Hiu: Hewan Primitif yang Memberikan Sumbangan Luar Biasa bagi Kesehatan Manusia. Warta Penelitian Perikanan Indonesia, 2(4): 2-7. 